\title{
Distribution patterns of small cetaceans in Galician waters
}

\author{
A. López ${ }^{\dagger}$, G.J. Pierce ${ }^{\ddagger}$, X. Valeiras ${ }^{\dagger}$, M.B. Santos ${ }^{\ddagger}$ and A. Guerra* \\ *Instituto de Investigaciones Marinas-CSIC, Eduardo Cabello, 6-36208, Vigo, Spain. \\ ${ }^{\dagger}$ Coordinadora para o Estudio dos Mamíferos Mariños, CEMMA, Apdo. 156-36380, Gondomar, Spain. \\ ${ }^{\ddagger}$ Department of Zoology, University of Aberdeen, Tillydrone Avenue, Aberdeen, AB24 2TZ, UK.

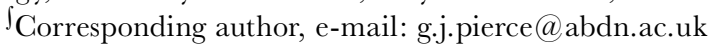

Cetacean sightings are reported from opportunistic deployment of observers on fishing boats during 1998-1999 in Galician waters (north-west Spain), a region of high biodiversity, intensive fishing activity and an important cetacean habitat. During 111 trips, a total track length of $8128 \mathrm{~km}$ and estimated area of approximately $9840 \mathrm{~km}^{2}$ was surveyed, including both inshore and offshore waters.

The most frequently sighted species were common dolphins (Delphinus delphis) and bottlenose dolphins (Tursiops truncatus). Taking account of biases in the survey data, the former species was most commonly sighted in deeper offshore waters (>200 m depth) with the highest sightings rate in the second quarter of the year. Bottlenose dolphins were seen mainly in inshore waters to the south of Galicia but also in offshore waters further north. Sightings rates were higher when the observers' boats were engaged in fishing than when travelling. Published dietary data suggest that this may simply indicate that dolphins tend to congregate in fishing areas where their main prey occur.

Several different treatments of the data were used to derive relative abundance indices (taking account of observation biases and of spatial variation in survey coverage). These calculations suggest that there may be around 7000-10,000 common dolphins and 600-1000 bottlenose dolphins in Galician waters, although dedicated surveys are needed to produce robust estimates.

Other species seen during surveys included the long-finned pilot whale (Globicephala melas), harbour porpoise (Phocoena phocoena), Risso's dolphin (Grampus griseus) and fin whale (Balaenoptera physalus). Incidental observations from boats and land-based surveys supported the high relative abundance of common dolphins and, in inshore waters, of bottlenose dolphins, as well as providing additional records of porpoises and Risso's dolphins.

\section{INTRODUCTION}

The Galician shelf lies at the northern limit of the east central Atlantic upwelling system. Upwelling occurs from April to September and, although relatively weak (Fraga, 1981), sustains a high productivity that, in turn, is expressed in high biodiversity, including some 300 species of fish (Solórzano et al., 1988) and over 75 species of cephalopods (Guerra, 1992). Galician waters are an important nursery ground for commercially important fish species such as hake (Merluccius merluccius), sardine (Sardinus pilchardus), scad (Trachurus trachurus) and blue whiting (Micromesistius poutassou).

At least 19 marine mammal species have been recorded from Galician waters (16 cetaceans and three pinnipeds; Penas-Patiño \& Piñeiro-Seage, 1989; Fernández de la Cigoña, 1990). The most commonly recorded cetacean species in strandings data from Galicia is the common dolphin (López et al., 2002).

Until 1985, sperm whales (Physeter macrocephalus) and rorquals such as fin whale (Balaenoptera physalus) were targeted by commercial whaling (Aguilar \& Lens, 1981) and most previous sightings surveys and abundance estimates concern these species (Aguilar et al., 1983, 1985; Mizroch \& Sanpera, 1984; Sanpera et al., 1984, 1985; Sanpera \& Jover, 1985, 1986, 1989; Lens et al., 1989). Published sightings records for smaller cetaceans in
Galician waters are scarce, and most refer to single observations, e.g. a school of common dolphins (Delphinus delphis) seen off Galicia in 1904 (Casinos \& Vericad, 1976), a group of striped dolphins (Stenella coeruleoalba) and two small groups of bottlenose dolphins (Tursiops truncatus) in 1977 (Grau et al., 1980) and sightings of single individuals of Risso's dolphin and killer whale (Orcinus orca) (Raga et al., 1985). The only previous systematic survey of small cetaceans was by Aguilar (1997). This provides some data on relative abundance, although not for the interior waters of the rías (Figure 1).

Galicia is the main fishing region of Spain and one of the most important in the world, with 87 fishing ports used by more than 6000 fishing boats along $1195 \mathrm{~km}$ of coastline (i.e. one port per $13.7 \mathrm{~km}$ and an average density of over five fishing boats per $\mathrm{km}$ of coastline). Excluding part-time fishermen, the fleet makes over one million fishing trips annually (see López et al., in press). The most numerous sector of the fishery consists of small boats (some 3000 of which are dedicated full-time to fishing) working in inshore waters using traps, trawls, gill-nets and longlines to target molluscs and crustaceans. Around 2000 boats work in offshore (littoral) waters. The offshore demersal fishery uses traps, longlines, trawls and gill-nets to take species such as hake, blue whiting, scad and monkfish, while purse seiners target sardine, scad and anchovy. This high level of fishing activity inevitably leads to interactions 


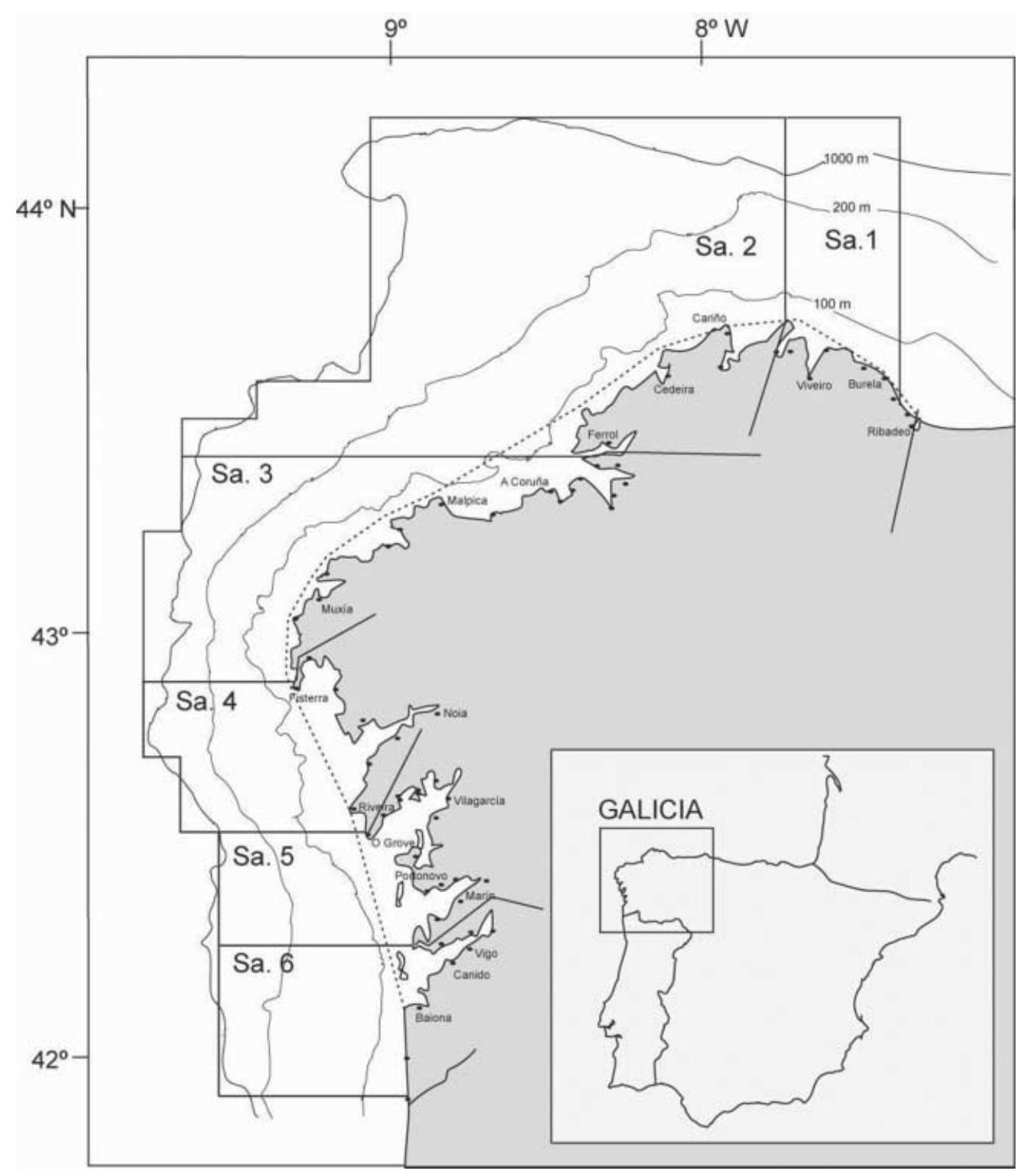

Figure 1. The study area, which consists of Galician coastal waters from the shore to the $1000 \mathrm{~m}$ isobath, from the Ría of Ribadeo in the north of Lugo region to the mouth of the river Miño in the south of Pontevedra region. The area was divided into six subareas (Sa. 1, Sa. 2, etc.), delimited by the following coastal locations (anticlockwise from the north-east): Estaca de Vares, Punta Segaño, Cabo Fisterra, Punta Couso, Cabo Home. The inshore zone is delimited by a minimum complex polygon joining the outermost points of the coast, and thus encompasses mainly areas with $<100 \mathrm{~m}$ depth. The $100 \mathrm{~m}, 200 \mathrm{~m}$ and $1000 \mathrm{~m}$ isobaths are shown, also the main fishing ports.

with resident cetacean populations. Offshore pair trawlers apparently regularly catch common dolphins (Aguilar, 1997) and around $20 \%$ of dead common dolphins found on the shore are by-catch mortalities (López et al., 2002). An interview survey (López et al., 2003) suggested that by-catch mortality was a common occurrence throughout Galician fisheries. However, information on distribution and abundance is required to put such findings in context.

The present report is based on opportunistic use of fishing vessels and a research boat as a platform for cetacean sightings over two years (1998-1999). The data are used to describe distribution patterns and to derive sightings rates and indices of relative abundance. In addition, we include information on incidental boat-based and land-based sightings recorded over the same period.

\section{MATERIALS AND METHODS}

Study area

The study area (Figure 1) extends from the coast to the $1000 \mathrm{~m}$ isobath, from the Ría of Rivadeo in the north of Lugo region to the mouth of the river Miño in the south of Pontevedra region. The estimated total surface area is $20,730 \mathrm{~km}^{2}$, including around $10,000 \mathrm{~km}^{2}$ on the continental shelf (AAVV, 1992). The Galician coastline has a length of $1195 \mathrm{~km}$ (50\% cliffs, 34\% low rocky shore, 16\% beaches). For retrospective spatial stratification of the survey area, the area was sub-divided from north to south into six sub-areas (Figure 1), also stratifying trip sectors according to water depth-classes $(<100 \mathrm{~m}, 100-200 \mathrm{~m}$, $>200 \mathrm{~m}$ ). 
Table 1. Survey coverage (number of survey sectors), cross-tabulated by gear-type, boat activity, season (quarter), depth-class, subarea and year. 'Artisanal' gears include traps and other gears used by small inshore boats. Overall depth-classes were $(I)<100 \mathrm{~m},(M)$ 100-200 m, (O) > 200 m. Activity-classes were (F) fishing, (T) travel and (F/T) a mixture of fishing and travel.

\begin{tabular}{|c|c|c|c|c|c|c|c|c|c|c|c|c|c|c|c|c|c|c|c|}
\hline \multirow[b]{2}{*}{ Gear } & \multirow[b]{2}{*}{ SUM } & \multicolumn{3}{|c|}{ By activity } & \multicolumn{4}{|c|}{ By quarter } & \multicolumn{3}{|c|}{ By depth-class } & \multicolumn{6}{|c|}{ By sub-area } & \multicolumn{2}{|c|}{ By year } \\
\hline & & $\mathrm{F}$ & $\mathrm{T}$ & $\mathrm{F} / \mathrm{T}$ & Q1 & Q2 & Q3 & $\mathrm{Q}^{4}$ & I & M & $\mathrm{O}$ & $\mathrm{S} 1$ & $\mathrm{~S} 2$ & S3 & $\mathrm{S} 4$ & S5 & S6 & 1998 & 1999 \\
\hline Artisanal & 71 & 64 & 6 & 1 & 5 & 41 & 7 & 18 & 71 & 0 & 0 & 24 & 0 & 0 & 0 & 47 & 0 & 32 & 39 \\
\hline Longline & 34 & 14 & 6 & 14 & 0 & 6 & 9 & 19 & 14 & 12 & 8 & 0 & 9 & 9 & 16 & 0 & 0 & 34 & 0 \\
\hline Seine & 53 & 14 & 24 & 15 & 0 & 8 & 26 & 19 & 53 & 0 & 0 & 0 & 5 & 28 & 12 & 8 & 0 & 44 & 0 \\
\hline Trawl & 724 & 504 & 219 & 1 & 33 & 117 & 204 & 370 & 140 & 388 & 196 & 5 & 239 & 45 & 213 & 138 & 84 & 264 & 9 \\
\hline (Research) & 107 & 107 & 0 & 0 & 0 & 0 & 107 & 0 & 23 & 25 & 59 & 0 & 35 & 21 & 13 & 15 & 23 & 107 & 460 \\
\hline \multirow[t]{2}{*}{ TOTAL } & 989 & 703 & 255 & 31 & 38 & 172 & 353 & 426 & 301 & 425 & 263 & 29 & 288 & 103 & 254 & 208 & 107 & 481 & 508 \\
\hline & & & & & \multicolumn{4}{|c|}{ By quarter } & \multicolumn{3}{|c|}{ By depth-class } & \multicolumn{6}{|c|}{ By sub-area } & \multicolumn{2}{|c|}{ By year } \\
\hline Activity & SUM & & & & Q1 & Q2 & Q3 & $Q^{4}$ & I & M & $\mathrm{O}$ & $\mathrm{S} 1$ & S2 & $\mathrm{S} 3$ & $\mathrm{~S} 4$ & $\mathrm{~S} 5$ & $\mathrm{~S} 6$ & 1998 & 1999 \\
\hline Fishing & 703 & & & & 38 & 99 & 246 & 320 & 134 & 365 & 204 & 29 & 211 & 84 & 167 & 130 & 82 & 334 & 369 \\
\hline Travel & 255 & & & & 0 & 70 & 99 & 86 & 141 & 91 & 23 & 0 & 62 & 11 & 82 & 75 & 25 & 119 & 136 \\
\hline $\mathrm{F} / \mathrm{T}$ & 31 & & & & 0 & 3 & 8 & 20 & 26 & 3 & 2 & 0 & 15 & 8 & 5 & 3 & 0 & 28 & 3 \\
\hline \multirow[t]{2}{*}{ TOTAL } & 989 & & & & 38 & 172 & 353 & 426 & 302 & 427 & 266 & 29 & 288 & 103 & 254 & 208 & 107 & 481 & 508 \\
\hline & & & & & & & & & \multicolumn{3}{|c|}{ By depth-class } & \multicolumn{6}{|c|}{ By sub-area } & \multicolumn{2}{|c|}{ By year } \\
\hline Quarter & SUM & & & & & & & & I & M & $\mathrm{O}$ & S1 & S2 & S3 & $\mathrm{S} 4$ & S5 & S6 & 1998 & 1999 \\
\hline Q1 & 38 & & & & & & & & 5 & 12 & 21 & 5 & 28 & 0 & 0 & 5 & 0 & 19 & 19 \\
\hline Q2 & 172 & & & & & & & & 67 & 32 & 73 & 24 & 43 & 0 & 17 & 81 & 7 & 114 & 58 \\
\hline Q3 & 353 & & & & & & & & 116 & 156 & 81 & 0 & 90 & 44 & 75 & 65 & 79 & 202 & 151 \\
\hline$\widetilde{Q}^{4}$ & 426 & & & & & & & & 113 & 259 & 54 & 0 & 127 & 59 & 162 & 57 & 21 & 146 & 280 \\
\hline \multirow[t]{2}{*}{ TOTAL } & 989 & & & & & & & & 301 & 459 & 229 & 29 & 288 & 103 & 254 & 208 & 107 & 481 & 508 \\
\hline & & & & & & & & & & & & \multicolumn{6}{|c|}{ By sub-area } & \multicolumn{2}{|c|}{ By year } \\
\hline Depth-class & SUM & & & & & & & & & & & $\mathrm{S} 1$ & $\mathrm{~S} 2$ & S3 & $\mathrm{S} 4$ & $\mathrm{~S} 5$ & $\mathrm{~S} 6$ & 1998 & 1999 \\
\hline I & 301 & & & & & & & & & & & 24 & 45 & 42 & 62 & 92 & 36 & 139 & 162 \\
\hline M & 459 & & & & & & & & & & & 2 & 15 & 57 & 166 & 57 & 62 & 167 & 292 \\
\hline $\mathrm{O}$ & 229 & & & & & & & & & & & 3 & 128 & 4 & 26 & 59 & 9 & 175 & 54 \\
\hline \multirow[t]{2}{*}{ TOTAL } & 989 & & & & & & & & & & & 29 & 288 & 103 & 254 & 208 & 107 & 481 & 508 \\
\hline & & & & & & & & & & & & \multicolumn{6}{|c|}{ By sub-area } & & \\
\hline Year & SUM & & & & & & & & & & & $\mathrm{S} 1$ & $\mathrm{~S} 2$ & S3 & $\mathrm{S} 4$ & S5 & $\mathrm{S} 6$ & & \\
\hline 1998 & 481 & & & & & & & & & & & 29 & 208 & 49 & 70 & 88 & 37 & & \\
\hline 1999 & 508 & & & & & & & & & & & 0 & 80 & 54 & 184 & 120 & 70 & & \\
\hline TOTAL & 989 & & & & & & & & & & & 29 & 288 & 103 & 254 & 208 & 107 & & \\
\hline
\end{tabular}

Surveys

Over two years, observers accompanied 98 trips on commercial fishing vessels in Galician waters (Table 1), covering a range of ports along the Galician coast and based on commercial fishing boats using several different fishing methods. Trips last between 45 min and $24 \mathrm{~h}$, with a median of $15.7 \mathrm{~h}$. For all trips, records were kept of the exact number of hours of observation. Total observation time was $802.4 \mathrm{~h}$ (range $30 \mathrm{~min}$ to $18 \mathrm{~h}$, median $8 \mathrm{~h}$ ). There were also 12 opportunistic trips accompanying the RV 'Cornide de Saavedra' (67 m length, 1113 tonnes) operated by Instituto de Investigaciones Marinas, during research trawling for hake. This contributed a further $115 \mathrm{~h}$ of observations. In all cases, the 'survey routes' were determined by the primary activities of the boats but were recorded by the observers. Although some surveys took place in all seasons, most effort was concentrated in the second half of the year (see Table 2). Fishing boats typically departed from ports at night, trawlers remaining at sea usually until the following night while boats deploying seine nets returned during the day.

A single observer was stationed on each boat. All observers had previous experience of working on fishing boats (as observers or crew) and in detection, identification and counting cetaceans at sea. Observations were carried out for continuous periods during daylight hours, both during fishing activities and while the boats were in transit. The positions of the observed parts of trips are shown in Figure 2. Regular sweeps were made with binoculars and 


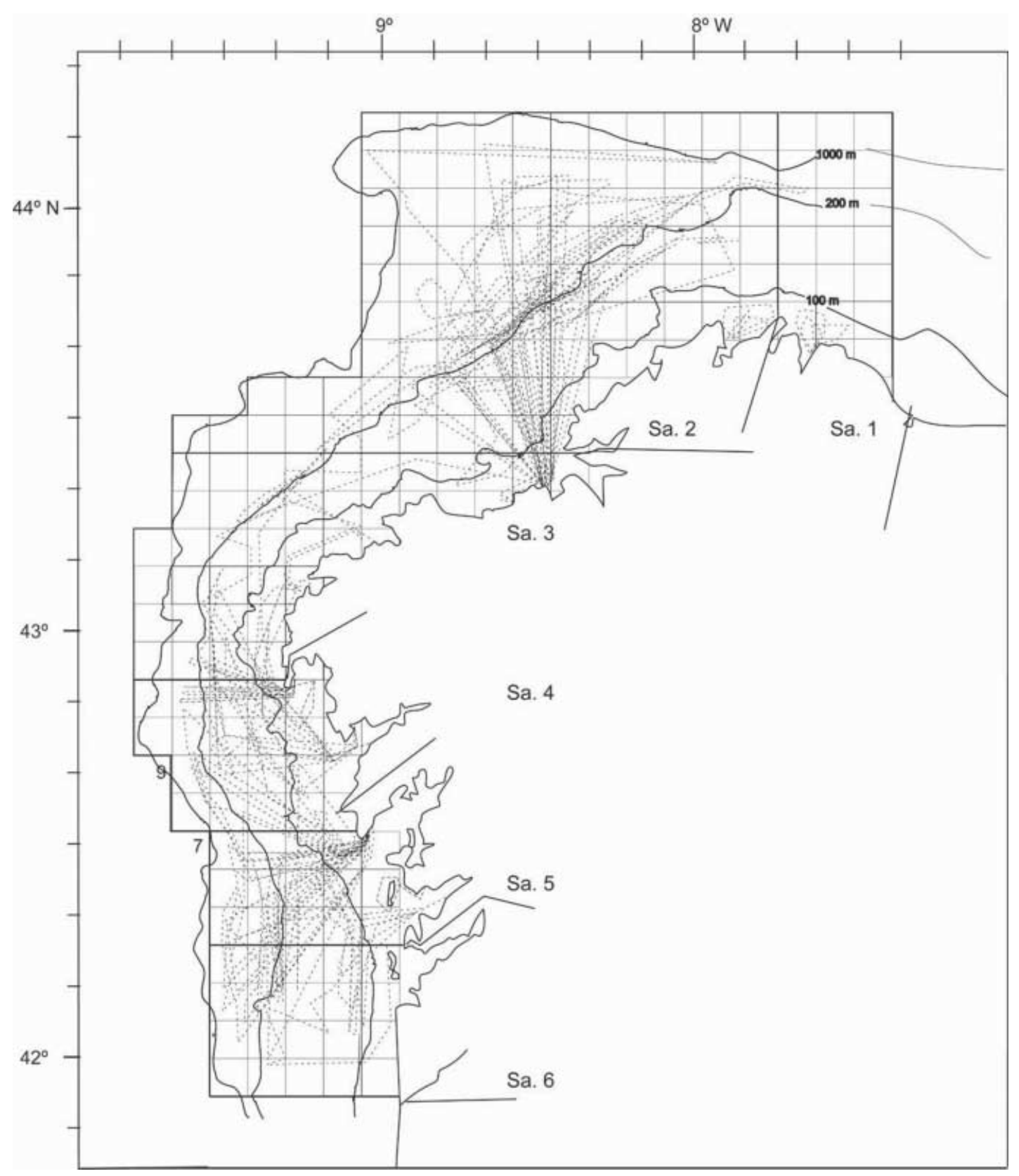

Figure 2. Survey routes. Observed tracklines are shown as dotted lines.

individual groups of cetaceans observed until they could be identified, group size estimated and their behaviour recorded. Data collected for each cetacean group included species, time, location, minimum and maximum estimates of group size, presence of calves, direction of travel and behaviour. By monitoring the position of groups, care was taken not to count the same groups of animals twice in succession-although this cannot always be ruled out. [The same animals may of course be sighted during different trips over the 2-y study period. Provided that cetaceans and boats do not display similar (or opposite) seasonal 'migrations', this should not result in any systematic error in the estimated sightings rates. Given the fairly broad spatio-temporal coverage of the study area by observers (see Tables $1 \& 2$ ), we would argue that multiple sightings of the same animals over the study period should not bias the estimates.]
Auxiliary data collected included regular updates of location, estimates of visible track width and whether the boat was fishing or travelling. This enabled all survey tracks to be retrospectively mapped and subdivided.

Visible track width was estimated for each trip based on visibility and sea state. Estimated visible track widths ranged from $140 \mathrm{~m}$ to $3 \mathrm{~km}$ (median $1 \mathrm{~km}$, i.e. $500 \mathrm{~m}$ each side of the boat). Typically, sea states of 3 or less on the Beaufort scale, with good visibility, would correspond to band widths of $1-2 \mathrm{~km}$. Narrower band widths correspond to sea states of Beaufort 4 and above and/or poor visibility. Clearly, effective track width would have been narrower for smaller species and the estimates provided by the observers are based on sightings of common dolphins, the most frequently sighted species. 


\section{Analysis of survey data}

The area surveyed during each boat trip was estimated from track length and visible track width and was retrospectively divided into sectors of approximately $10 \mathrm{~km}^{2}$ (989 sectors totalling $9842 \mathrm{~km}^{2}$ over the 110 surveys; total track length $8128 \mathrm{~km}$ or 4387 n.m.). Each sector was then assigned values for location (sub-area), [boat] activity (fishing and/or travel), [boat] velocity, and water depth $(<100 \mathrm{~m}, 100-200 \mathrm{~m}$ or $>200 \mathrm{~m})$. Estimated sighting rates (numbers of animals seen per $10 \mathrm{~km}^{2}$ of transect) were calculated for each sector. Boats were classified according to the type of vessel (commercial or research) and gear deployed, resulting in five categories: research, trawl, seine, lines and 'artisanal'. The latter comprises various traditional fishing methods used mainly by small boats in inshore waters, notably deployment of traps. For the purposes of investigation of temporal patterns, dates were grouped by season (quarter of the year) and year (1998 or 1999).

Due to logistic limitations, the approach used corresponds approximately to strip transect rather than line transect or distance sampling methodology. The data arise from opportunistic use of boat trips and a single observer was present on each boat; the boats did not follow predetermined survey routes; boats varied in size and travel speed was not constant. During most trips, it was considered impractical to attempt to measure distance of cetaceans from the boats which, unfortunately, precludes direct estimation of effective track width for each species and hence estimation of absolute densities. It was not possible to estimate the proportion of cetaceans not seen by observers (i.e. those which were underwater or surfaced out of the field of view of the observer). For larger cetacean species and slow boat travel speeds (e.g. during fishing), detection probability may nevertheless have approached 1.0.

To attempt to isolate effects of different explanatory variables on sightings rates, multiple regression analysis was used. For this analysis, presence rather than sightings rate as the response variable was used, thereby eliminating the effect of extreme values. All factors were recoded into dummy variables, each of which could take the value 1 or 0 . Thus water depth (three categories) was coded into two dummy variables, '<100 m' and '> $200 \mathrm{~m}$ ', season (four categories) into three variables, and so on. Sector number was recoded into two dummy variables indicating ranges of sector numbers, ' $1-5$ ' and ' $6-10$ '. Track width was coded into two dummy variables, ' $\leqslant 1 \mathrm{~km}$ ' and ' $1-2 \mathrm{~km}$. Velocity was not included in the analysis since it proved to relate very closely to (boat) activity.

Additionally, effects of individual factors on sightings rates were analysed using Kruskal-Wallis tests (for effects of season, year, sub-area, water depth, boat activity, boat type) and Spearman's rank correlations (for effects of boat velocity, visible track width, sector number). If 'visible track width' adequately accounted for differences in visibility related to weather and sea state, we would expect sightings rates to be independent of track width. Similarly, if sightings rates were unaffected by observer fatigue, they would be expected to be independent of sector number. Fatigue would tend to result in lower sightings rates for later sectors (higher sector numbers). Relationships between the different putative explanatory variables were also explored to enable identification of possible confounding effects, using Kruskal-Wallis (for ordinal variables) and Chi-squared (for categorical variables) tests.

For the most common species, crude abundance indices were derived from the total number of animals seen (mean counts, i.e. minimum + maximum $/ 2$ ), divided by the estimated area surveyed and multiplied by estimated total area surveyed (i.e. all summed counts are multiplied by 20,390/9842). The analysis of sightings rates indicated several possible sources of negative bias and adjusted estimates were derived by excluding sectors in which sightings rates might have been reduced by these biases.

The above estimates ignored differences in sightings rates between different areas. To provide more robust abundance indices, the survey area was stratified by water depth and sub-area. Some of the 18 spatial strata thus defined were poorly sampled and the stratification was therefore partially collapsed to ensure reasonable sample sizes within each stratum (see Table 2). For the stratified indices, a bootstrap re-sampling procedure, with 10,000 repeats, was applied to the entire dataset to estimate $95 \%$ confidence limits for the number of animals present. It should be stressed that these confidence limits take account only of variability in observed sightings rates and do not address biases underlying the measurements.

\section{Incidental observations and land-based surveys}

Incidental observational data were obtained from a fisherman (a member of the local voluntary cetacean strandings network, CEMMA) for 123 days fishing north of Pontevedra (sub-area 5), which yielded sightings on 23 days, and from observers on ferries in the rías of Vigo and Pontevedra (31 days). There were also monthly coastal sightings surveys (Días de Observación Costeira de Cetáceos, DOCGE) organized by CEMMA, which took place on one day each month from January 1998 to December 1999. A total of 130 observers was involved, completing $855 \mathrm{~h}$ of observations. Observations usually took place from coastal sites several metres above sea level and with the aid of binoculars. Data collected included sightings, area covered, time, weather, wind, sea conditions and visibility. Four volunteer groups of CEMMA - those based in Bayona, Pontevedra, Noia and a mobile unit (for visiting strandings) - contributed a further 986 hours of coastal observation.

\section{RESULTS}

\section{Boat-based surveys: physical parameters}

Records were obtained for sightings in 989 survey sectors of $\sim 10 \mathrm{~km}^{2}$, the majority during fishing (703), others during travelling (255) or including both activities (31). Observations took place on fishing vessels deploying four categories of fishing gears (artisanal, lines, seines, trawls), with over two-thirds of all observed sectors being viewed from trawlers, as well as on a research fishing vessel. All observations on the research vessel and most on artisanal vessels took place during fishing whereas around $30 \%$ of observations on trawlers took place while the boat was travelling. The association between boat-type and activity was significant $\left(\chi^{2}=374.6, P<0.001\right)$. 
Table 2. Definition of survey spatial strata (in terms of sub-area and sea depth), the number of survey sectors within each habitat during each season, the area occupied by each habitat in the study area and the total area surveyed within each habitat stratum.

\begin{tabular}{|c|c|c|c|c|c|c|c|c|c|c|}
\hline \multirow{2}{*}{$\begin{array}{l}\text { Spatial } \\
\text { stratum }\end{array}$} & \multirow{2}{*}{$\begin{array}{l}\text { Sub-area } \\
\text { code }\end{array}$} & \multirow{2}{*}{$\begin{array}{l}\text { Depths } \\
(\mathrm{m})\end{array}$} & \multirow{2}{*}{$\begin{array}{l}\text { Number } \\
\text { of sectors }\end{array}$} & \multicolumn{4}{|c|}{ Sectors per season } & \multirow{2}{*}{$\begin{array}{c}\text { Area of } \\
\text { stratum }\left(\mathrm{km}^{2}\right)\end{array}$} & \multirow{2}{*}{$\begin{array}{c}\text { Area } \\
\text { surveyed }\left(\mathrm{km}^{2}\right)\end{array}$} & \multirow{2}{*}{$\begin{array}{c}\text { Proportion } \\
\text { surveyed }\end{array}$} \\
\hline & & & & 1 & 2 & 3 & 4 & & & \\
\hline 1 & $1+2$ & $<100$ & 69 & 0 & 26 & 6 & 37 & 1255 & 690 & 0.55 \\
\hline 2 & $1+2$ & $100-200$ & 117 & 12 & 11 & 29 & 65 & 3550 & 1170 & 0.33 \\
\hline 3 & $1+2+3$ & $>200$ & 135 & 21 & 30 & 59 & 25 & 7445 & 1350 & 0.18 \\
\hline 4 & 3 & $<100$ & 42 & 0 & 0 & 21 & 21 & 1225 & 420 & 0.34 \\
\hline 5 & 3 & $100-200$ & 57 & 0 & 0 & 19 & 38 & 1000 & 570 & 0.57 \\
\hline 6 & 4 & $<100$ & 62 & 0 & 4 & 29 & 29 & 670 & 620 & 0.93 \\
\hline 7 & 4 & $100-200$ & 166 & 0 & 6 & 37 & 123 & 725 & 1660 & 2.29 \\
\hline 8 & 4 & $>200$ & 26 & 0 & 7 & 9 & 10 & 600 & 260 & 0.43 \\
\hline 9 & 5 & $<100$ & 92 & 5 & 36 & 25 & 26 & 694 & 920 & 1.33 \\
\hline 10 & 5 & $100-200$ & 57 & 0 & 11 & 28 & 18 & 500 & 570 & 1.14 \\
\hline 11 & $5+6$ & $>200$ & 68 & 0 & 36 & 13 & 19 & 1200 & 680 & 0.57 \\
\hline 12 & 6 & $<100$ & 36 & 0 & 1 & 35 & 0 & 526 & 360 & 0.68 \\
\hline \multirow[t]{2}{*}{13} & 6 & $100-200$ & 62 & 0 & 4 & 43 & 15 & 1000 & 620 & 0.62 \\
\hline & & SUM & 989 & 38 & 172 & 353 & 426 & 20,390 & 9890 & \\
\hline
\end{tabular}

Although the geographical and seasonal coverage of observations from trawlers was good, observations from the other three commercial vessel categories were generally restricted to certain season/sub-area/depth-class categories. Observations from boats using artisanal gears and seine nets were restricted to shallow $(<100 \mathrm{~m})$ waters $($ see Table 1). The associations of gear type with water depth $\left(\chi^{2}=332.3, P<0.001\right)$ and season $\left(\chi^{2}=312.4, P<0.001\right)$ were both highly significant. Although most fishing was observed in waters of intermediate depth, observations during travelling occurred most often in shallower waters, because they were often taken as the boat returned to port. Again this is reflected in a significant association between boat activity and water depth $\left(\chi^{2}=166.9\right.$, $P<0.001)$.

During fishing, median boat velocity was 3.5 knots whereas median velocity during travelling was 9.5 knots. For mixed (fishing and travel) sectors, the median velocity was 7 knots. This variation in average velocity in relation to activity is highly significant (Kruskal-Wallis test, $\mathrm{H}=496.9, P<0.001)$. Furthermore there was a strong relationship between sector number and boat activity, with higher sector numbers (i.e. sectors towards the end of each trip) tending to be associated with travelling (Kruskal-Wallis test, $\mathrm{H}=171.2, \quad P<0.001$ ). This arose because observers carried on taking observations as the boats returned to port. Related to this, median boat velocity in shallow waters was higher than in intermediate or deep waters (Kruskal-Wallis test, $\mathrm{H}=171.6, \quad P<0.001$ ). Similarly there was a higher proportion of low sector numbers in deep water than in intermediate or shallow water (Kruskal-Wallis test, $\mathrm{H}=73.0, P<0.001$ ). Higher sector numbers tended to be associated with trawlers and the research vessel (Kruskal-Wallis test, $\mathrm{H}=154.1$, $P<0.01$ ), because the longest trips were on these vessels.

Two other limitations in the data are apparent from Table 1: (a) sub-area 1 was surveyed only in the first half of the year whereas the other sub-areas were surveyed more often in the second half of the year; (b) the deepwater $(>200 \mathrm{~m}$ ) sector was not well-covered in sub-areas 1,3 and 6 (Table 1). Consequently, for derivation of average sightings rates, the intended spatial stratification of the study area by sub-area-depth-class was partially collapsed (from 18 to 13 strata), by merging poorly surveyed areas with adjacent ones (Table 2). Estimated survey coverage of each stratum ranges from $20 \%$ of the surface area of stratum 3 (northern areas, deep water) to $230 \%$ of stratum 7 (sub-area 4 , intermediate depths).

\section{Boat surveys: cetaceans seen}

The most commonly seen cetacean species, occasionally in large groups (over 1000 animals), was the common dolphin (Table 3). Data on mean numbers sighted per sector show that this species occurs all along the Galician coast (Table 4) although sightings rates were generally highest in waters over $200 \mathrm{~m}$ in depth.

The bottlenose dolphin was the second most commonly seen species, with the highest sightings rate in inshore waters of sub-area 5 , but there were also several sightings in sub-areas 1-3 in the north, including in deep water ( $>200 \mathrm{~m}$ ). Long-finned pilot whales were the third most frequently seen species, being recorded on seven occasions, mainly in deep waters in the central and northern part of the study area (Table 4). Harbour porpoises were seen on three occasions in shallow waters in sub-area 5 and there were single sightings of Risso's dolphins and fin whales.

\section{Variability in numbers of animals sighted}

\section{Stepwise multiple regression of presence/absence data}

Stepwise multiple regression analysis for presence of cetaceans (all species together) identified three explanatory factors, coding for sector number, water depth and boat activity, which together accounted for $4.5 \%$ of variation in presence/absence of sightings. Cetacean presence was positively associated with sectors $1-5$ of surveys, water depths $>200 \mathrm{~m}$ and fishing activity. These results suggest that observer fatigue led to reduced sightings rates in later sectors but that, accounting for this effect, cetaceans were seen most often in deep water and during fishing. Since over half of the observations made while 
Table 3. Numbers of cetaceans seen during surveys (number of groups and sums of minimum, mean and maximum counts), number of sectors in which they were seen and average group size.

\begin{tabular}{|c|c|c|c|c|c|c|}
\hline Species & $\begin{array}{c}\text { Presence } \\
\text { (number } \\
\text { of sectors) }\end{array}$ & $\begin{array}{l}\text { No. of } \\
\text { groups }\end{array}$ & $\begin{array}{l}\text { Sum of } \\
\text { mininum } \\
\text { counts }\end{array}$ & $\begin{array}{l}\text { Sum of } \\
\text { mean } \\
\text { counts }\end{array}$ & $\begin{array}{c}\text { Sum of } \\
\text { maximum } \\
\text { counts }\end{array}$ & $\begin{array}{l}\text { Mean } \\
\text { group size } \\
(\text { SD })\end{array}$ \\
\hline Balaenoptera physalus & 1 & 1 & 1 & 2 & 3 & $2(0)$ \\
\hline Delphinus delphis & 76 & 95 & 3081 & 3500 & 3918 & $37.3(129.1)$ \\
\hline Globicephala melas & 6 & 7 & 80 & 86 & 91 & $12.2(21.7)$ \\
\hline Grampus griseus & 1 & 1 & 1 & 1 & 1 & $1(0)$ \\
\hline Phocoena phocoena & 3 & 3 & 8 & 9 & 10 & $3.0(1.8)$ \\
\hline Tursiops truncatus & 19 & 21 & 268 & 291 & 313 & $13.8(11.0)$ \\
\hline Unidentified delphinid & 4 & 4 & 30 & 35 & 40 & $8.8(5.9)$ \\
\hline Unidentied mysticete & 1 & 1 & 1 & 1 & 1 & $1(0)$ \\
\hline TOTAL & 104 & 136 & 3470 & 3921 & 4372 & \\
\hline
\end{tabular}

travelling took place in shallow water (see Table 1), effects of boat activity and travel depth might be confounded but this analysis suggests that there are separate effects of activity and depth. The more frequent presence of cetaceans during fishing may simply indicate that cetaceans tend to be found where fish are found but could also indicate bias, either due to increased probability of sightings at slower velocities or to cetaceans being attracted to fishing vessels. For common dolphins, presence was significantly related to three explanatory factors coding for depth and sector. Again, the overall proportion of variance explained $(4.6 \%)$ was low. Common dolphin presence was positively associated with water depths $>200 \mathrm{~m}$, negatively associated with water depths of $<100 \mathrm{~m}$, and positively associated with sectors $1-5$ of surveys.

In the case of bottlenose dolphins, three variables coding for fishing method and track width together explained 2.8\% of variation. Presence of bottlenose dolphins was positively associated with artisanal gears and seine nets and negatively associated with track widths of $\leqslant 1 \mathrm{~km}$.

\section{Univariate analyses of sightings rates}

Results from univariate analyses of the average number of sightings per sector are summarized in Table 5. Since putative explanatory factors were considered in isolation, interactions and confounding effects cannot be ruled out.

Considering all cetacean species together, the most important factors affecting numbers sighted appear to be water depth, sector number, boat activity and boat velocity. Boat activity and boat velocity are closely related and the trend appears to be that many more sightings occur during fishing than travel. [There were no sightings during the (relatively few) periods of mixed travel/ fishing]. There was no effect of visible track width on sightings rate, suggesting that estimated track width adequately accounted for variation in visibility. The sightings rate in deep water (>200 $\mathrm{m}$ depth) was higher than in intermediate depth or shallow waters.

Considering data for common dolphins alone, it is again apparent that sightings rates were lower when boats were travelling rather than fishing, fewer dolphins were seen in later sectors, and there was a clear trend for sightings rates to be higher in deeper water. Note that the mean sighting rate was highest at intermediate depth (5.1 dolphins per sector as compared to 4.6 in waters $>200 \mathrm{~m}$ and 0.3 in waters $<100 \mathrm{~m}$ ) but this was strongly influenced by sightings of a few large groups of dolphins. Both parametric and non-parametric analyses agree that fewest common dolphins were present in waters $<100 \mathrm{~m}$ deep.

Table 4. Mean (with standard deviation) sightings rates (animals per $10 \mathrm{~km}^{2}$ sector) for three most common species for each spatial stratum. Spatial strata were defined in terms of water depths and geographical sub-areas (see Figure 1).

\begin{tabular}{|c|c|c|c|c|c|}
\hline $\begin{array}{l}\text { Spatial } \\
\text { stratum }\end{array}$ & $\begin{array}{l}\text { Sub-area } \\
\text { code }\end{array}$ & $\begin{array}{l}\text { Depths } \\
\text { (m) }\end{array}$ & $\begin{array}{c}\text { Common } \\
\text { dolphin }\end{array}$ & $\begin{array}{c}\text { Bottlenose } \\
\text { dolphin }\end{array}$ & $\begin{array}{l}\text { Long-finned } \\
\text { pilot whale }\end{array}$ \\
\hline 1 & $1+2$ & $<100$ & $0.00(0.00)$ & $0.15(1.20)$ & $0.00(0.00)$ \\
\hline 2 & $1+2$ & $100-200$ & $0.80(4.11)$ & $0.20(1.65)$ & $0.07(0.54)$ \\
\hline 3 & $1+2+3$ & $>200$ & $5.13(19.61)$ & $0.56(3.75)$ & $0.47(5.42)$ \\
\hline 4 & 3 & $<100$ & $0.81(4.07)$ & $0.18(1.01)$ & $0.00(0.00)$ \\
\hline 5 & 3 & $100-200$ & $0.82(3.72)$ & $0.00(0.00)$ & $0.04(0.26)$ \\
\hline 6 & 4 & $<100$ & $0.00(0.00)$ & $0.02(0.13)$ & $0.00<0.000$ \\
\hline 7 & 4 & $100-200$ & $1.74(12.66)$ & $0.02(0.31)$ & $0.02(0.23)$ \\
\hline 8 & 4 & $>200$ & $7.94(17.36)$ & $0.00(0.00)$ & $0.37(1.86)$ \\
\hline 9 & 5 & $<100$ & $0.16(1.29)$ & $1.56(7.90)$ & $0.00(0.00)$ \\
\hline 10 & 5 & $100-200$ & $0.29(2.19)$ & $0.00(0.00)$ & $0.00(0.00)$ \\
\hline 11 & $5+6$ & $>200$ & $2.18(7.52)$ & $0.38(2.26)$ & $0.00(0.00)$ \\
\hline 12 & 6 & $<100$ & $0.83(5.00)$ & $0.00(0.00)$ & $0.00(0.00)$ \\
\hline 13 & 6 & $100-200$ & $31.10(159.9)$ & $0.00(0.00)$ & $0.00(0.00)$ \\
\hline
\end{tabular}


Table 5. Summary of univariate statistical analysis of factors affecting mean sightings rate. All categorical factors were analysed with Kruskal-Wallis tests (for which values of $H$ and the associated probability are given) and effects of boat velocity, track width and sector number were analysed with Spearman's rank correlation (values of $r_{s}$ and probability are given). When Kruskal-Wallis tests were significant, Mann-Whitney tests were used to identify which groups differed from each other. Note: there were no sightings of any cetaceans during sectors with mixed fishing/travel activity; there were no sightings of Tursiops during research fishing trips.

\begin{tabular}{|c|c|c|c|c|}
\hline Species & Factor & $\begin{array}{c}\text { Test } \\
\text { statistic }\end{array}$ & Probability & $\begin{array}{l}\text { Significant differences } \\
\text { and trends }\end{array}$ \\
\hline \multirow[t]{9}{*}{ All species } & Depth-class & 25.16 & $<0.001$ & Deep $>$ medium, shallow \\
\hline & Boat activity & 20.47 & $<0.001$ & fishing $>$ travel \\
\hline & Sector number & -0.176 & $<0.001$ & Negative correlation \\
\hline & Boat velocity & -0.137 & $<0.001$ & Negative correlation \\
\hline & Season & 6.30 & 0.098 & - \\
\hline & Track width & -0.04 & 0.242 & - \\
\hline & Fishing gear & 3.33 & 0.504 & - \\
\hline & Year & 0.34 & 0.559 & - \\
\hline & Sub-area & 2.06 & 0.841 & - \\
\hline \multirow{9}{*}{ Delphinus delphis } & Depth-class & 36.72 & $<0.001$ & Deep $>$ medium $>$ shallow \\
\hline & Boat velocity & -0.149 & $<0.001$ & Negative correlation \\
\hline & Sector number & -0.123 & $<0.001$ & Negative correlation \\
\hline & Boat activity & 12.69 & 0.002 & Fishing $>$ travel \\
\hline & Season & 7.91 & 0.048 & $\mathrm{Q}_{2}>\mathrm{Q}_{3}, \mathrm{Q}^{4}$ \\
\hline & Fishing gear & 6.49 & 0.165 & - \\
\hline & Year & 0.99 & 0.320 & - \\
\hline & Track width & -0.03 & 0.340 & - \\
\hline & Sub-area & 5.16 & 0.397 & - \\
\hline \multirow[t]{9}{*}{ Tursiops truncatus } & Fishing gear & 24.15 & $<0.001$ & Artisanal, seine $>$ trawl \\
\hline & Sector number & -0.100 & 0.002 & negative correlation \\
\hline & Depth-class & 7.65 & 0.022 & Shallow, deep $>$ medium \\
\hline & Sub-area & 10.69 & 0.058 & - \\
\hline & Boat activity & 3.32 & 0.190 & - \\
\hline & Season & 4.45 & 0.217 & - \\
\hline & Boat velocity & -0.03 & 0.464 & - \\
\hline & Track width & -0.02 & 0.539 & - \\
\hline & Year & 0.01 & 0.911 & - \\
\hline
\end{tabular}

The sightings rate in quarter 2 was significantly higher than in quarters 3 or 4.

In the case of bottlenose dolphin sightings, effects of boat activity, boat velocity and season were non-significant, while the difference between sub-areas is only just non-significant. Fewer dolphins were seen during later sectors of trips. There was a significant effect of depth, with fewest animals being seen in the intermediate (100$200 \mathrm{~m}$ ) depth range. Interestingly there was also a strong effect of the type of boat: bottlenose dolphins were sighted more frequently from boats deploying artisanal gears and seine nets than from boats engaged in trawling. Both artisanal and seine gears were observed only in shallow waters, indicating that depth and gear effects are not entirely independent. However, trawling was observed with similar relative frequency in both deep and intermediate depth waters (Table 1) and the difference in sightings rate between these two depth strata thus appears not to be related to boat type.

\section{Relative abundance indices}

Treating data from all sectors equally, assuming track widths to have been accurately estimated and the probability of sighting cetaceans present along the track to be 1.0, the observed sightings rates correspond to the presence of over 7000 common dolphins, around
600 bottlenose dolphins and under 200 long-finned pilot whales (Table 6). The latter estimate was strongly influenced by a single sighting of one large group (50-60 animals).

Analysis of factors affecting presence and rate of sightings suggested that observer fatigue might reduce sightings during later survey sectors and that most sightings were made during fishing (at low boat velocity). Furthermore, for bottlenose dolphins, there were fewer sightings when estimated visible track width was narrowest. Further exploration of the data indicated that 96 of the 104 sectors in which there were sightings were between the 1st and 10th sectors of trips, the boat was fishing during 93 sectors with sightings and 101 sectors with sightings had visible track widths $\geqslant 1 \mathrm{~km}$. Excluding sectors numbered 11 or over, sectors in which the boat was not fishing and sectors with track widths $<1 \mathrm{~km}$, the remaining dataset comprises 578 sectors $\left(\sim 5780 \mathrm{~km}^{2}\right)$. Sightings rates in these sectors correspond to the presence of around 10,000 common dolphins, 1000 bottlenose dolphins and 300 longfinned pilot whales (Table 6). However, it must be borne in mind that there could be positive biases when sampling from boats, especially in the vicinity of fishing activity.

Ignoring possible biases but taking account of differences in sightings rates between different spatial strata, the number of common dolphins present in the area was estimated to be around 8100 animals. The wide 95\% 
Table 6. Abundance estimates for the most common cetacean species seen during surveys. The uncorrected estimates treat all survey sectors as equivalent. The adjusted estimates exclude sectors for which there may have been a negative bias in estimated sightings rates. The stratified estimates use data for all sectors but take into account differences in coverage of different survey spatial strata and associated sampling errors.

\begin{tabular}{|c|c|c|c|}
\hline Species & Uncorrected & Adjusted & $\begin{array}{c}\text { Stratified, with } \\
\text { 95\% CL }\end{array}$ \\
\hline Delphinus delphis & 7245 & 9858 & $\begin{array}{c}8137 \\
(4388-13678)\end{array}$ \\
\hline Globicephala melas & 178 & 302 & $\begin{array}{c}385 \\
(13-1131)\end{array}$ \\
\hline Tursiops truncatus & 603 & 968 & $\begin{array}{c}664 \\
(251-1226)\end{array}$ \\
\hline ALL & 8123 & 13832 & $\begin{array}{c}9305 \\
(5368-14823)\end{array}$ \\
\hline
\end{tabular}

CL, confidence limits.

Table 7. Population parameters for common dolphins (with 95\% confidence limits if available) from three studies. The MICA survey covered offshore waters west of France (Goujon et al., 1993), the SCANS survey data are for the Celtic Shelf (Hammond et al., 1995).

\begin{tabular}{|c|c|c|c|}
\hline Parameter & This study & MICA & SCANS \\
\hline $\begin{array}{l}\text { Population } \\
\text { size }\end{array}$ & $\begin{array}{c}8137 \\
(4388-13678)\end{array}$ & $\begin{array}{c}61888 \\
(35461-108010)\end{array}$ & $\begin{array}{c}75449 \\
(22900-248900)\end{array}$ \\
\hline $\begin{array}{l}\text { School } \\
\text { abundance }\end{array}$ & $\begin{array}{c}261 \\
(191-346)\end{array}$ & - & 6986 \\
\hline $\begin{array}{l}\text { Mean } \\
\quad \text { school } \\
\text { size }\end{array}$ & 37.2 & - & 10.8 \\
\hline $\begin{array}{l}\text { Median } \\
\text { school size }\end{array}$ & 10.5 & - & - \\
\hline $\begin{array}{l}\text { Density } \\
\qquad(\text { dolphins/ } \\
\left.\mathrm{km}^{2}\right)\end{array}$ & $\begin{array}{c}0.399 \\
(0.215- \\
0.671)\end{array}$ & - & 0.374 \\
\hline
\end{tabular}

confidence limits (4400-14,000) reflect the patchy distribution of sightings and wide range of group sizes. Estimates of density and average school size for the common dolphin population appear in Table 7. Under similar assumptions, there would be around 660 (95\% confidence limits 250-1230) bottlenose dolphins in the area. The stratified estimate for long-finned pilot whales approached 390 animals (Table 6).

\section{Other observations}

Observations provided by a fisherman during 19981999 comprised recorded sightings of 30 groups of bottlenose dolphins, five groups of harbour porpoises and two groups each of common and Risso's dolphins, seen over 23 days out of 123 days fishing in inshore waters. Observations from 31 ferry trips included 28 sightings of marine mammals, all of which were either common or bottlenose dolphins. The monthly coastal sightings surveys yielded 11 sightings, again all of common and bottlenose dolphins, totalling around 230 individuals. Around half of these sightings (128 animals) were bottlenose dolphins seen in the rías of Noia and Vigo (sub-areas 4 and 6 respectively) and near La Coruña (sub-area 3). Additional coastal surveys by CEMMA yielded 108 sightings in 986 hours. The high frequency of bottlenose dolphin sightings during coastal surveys is consistent with their coastal distribution.

\section{DISCUSSION}

There has been little previous work on cetacean distribution or abundance in Spanish waters, and most published studies refer to fin whales off western Spain during the 1980s (Aguilar et al., 1983, 1985; Mizroch \& Sanpera, 1984; Sanpera et al., 1984, 1985; Sanpera \& Jover, 1985, 1986, 1989; Lens et al., 1989). Two recent studies collated data on strandings and fishery by-catches of cetaceans in Galician waters (López et al., 2002, 2003).

In the only comparable study for Galicia, Aguilar (1997) reported results of opportunistic surveys from fishing boats, covering 1635 nautical miles of survey track. This compares to 4387 n.m. covered in the present study, which was also more complete in that it included the interior waters of the rías (all within the $100 \mathrm{~m}$ isobath). Aguilar also found common dolphin to be the most abundant species present (97 groups observed west of Galicia and ten groups observed to the north). Only four groups of bottlenose dolphins were seen, but he acknowledged that the surveys did not adequately cover the interior of the rías.

In the present study, surveys were non-random and opportunistic, and mainly concentrated in the second half of the year. There is evidence that sightings rates were higher earlier during trips and when the boat being used as a platform was fishing. The former trend is consistent with observer fatigue while the latter could be explained in several ways. Observers may be less likely to detect cetaceans at faster speeds, cetaceans may be attracted to slowmoving boats or cetaceans may be feeding in the areas used for fishing. Finally, there was evidence of a reduced frequency of bottlenose dolphin sightings when visibility was poorest (narrowest estimated track width). However, when these biases were taken into account, there remained clear evidence of differences in sightings rates in relation to water depth (or distance from the shore) and, in the case of common dolphins, season.

Common dolphins were seen throughout the study area, but sightings rates were highest in the second quarter of the year and in deep water $(>200 \mathrm{~m})$, where most interactions with fishing activity are likely to take place. Aguilar (1997) recorded common dolphins being by-caught by pair-trawlers in offshore waters.

Evans (1980) suggests that movements of common dolphins in UK waters are associated with movements of mackerel and herring. In Galician waters, common dolphins apparently feed mainly on blue whiting (Micromesistius poutassou), scads (Trachurus spp.) and sardine (Sardinus pilchardus) (Santos, 1998). All are pelagic shoaling species also targeted by Galician fishermen. Thus, both the association of common dolphin sightings with fishing and their occurrence mainly in deeper offshore waters may simply relate to feeding behaviour. Concerning seasonal variation in sightings rate, Collet (1981) indicates that the peak of breeding in common dolphins in the eastern North 
Atlantic occurs in May and June, however it is not clear that this would necessarily affect the likelihood of sightings.

While there is much general information on distribution and abundance of common dolphins in the north-east Atlantic, few studies have quantified abundance. In UK waters the common dolphin is most commonly seen off the south and south-west coasts of Britain and Ireland, especially between June and December. Large numbers have also been seen off north-east Scotland (Evans, 1980), although it is not among the species recorded in the Faroe-Shetland Channel by Bloor et al. (1996). It is rare amongst strandings on the Belgian and Dutch coasts (De Smet, 1974; van Bree, 1977) but very abundant off the coasts of Spain, Portugal, the Gulf of Gascony and Brittany (Cabrera, 1914; Casinos \& Vericad, 1976; Duguy, 1977; Evans, 1980; Sequeira \& Teixeira, 1988; Dos Santos et al., 1988). Sequeira \& Inácio (1992) reported that it was the most common cetacean off the Portuguese coast. It is the most commonly stranded species on the Iberian coast (Cendrero, 1993; López et al., 2002).

The median school size for common dolphins in the present study was rather lower than the mean value (Table 7), which was strongly influenced by observations of a few large schools, including one of 1000-1500 dolphins. Although common dolphins usually aggregate in small schools, with a modal size at around eight dolphins, big concentrations from 1000 to 5000 animals have been recorded previously (Tomilin, 1957; Ross, 1984; Gaskin, 1992), including previous records for Galician waters (Vázquez et al., 1996).

Population estimates for common dolphins are available from the SCANS survey (Hammond et al., 1995) for the Celtic Shelf (off south-west Ireland) and from the MICA survey (Goujon et al., 1993) for the Bay of Biscay. Although our data are clearly subject to various biases and errors (not least because track width was estimated by the observer rather than measured), the median school size and average population density for common dolphins in the present study were in good agreement with results from Hammond et al. (1995) for the Celtic Shelf (see Table 7) and it could be argued that this similarity provides some support for our abundance estimates. Our results suggest that there could be 7000-10,000 common dolphins living in Galician waters, an order of magnitude higher than numbers of bottlenose dolphins. The Galician 'population' of common dolphins may be part of a wider population including animals from the Bay of Biscay and Portuguese coasts. Recent genetic studies suggested that Delphinus delphis in the Atlantic is differentiated from the Mediterranean population but provided no evidence of significant genetic divergence between animals from Galician, Portuguese and UK waters (Natoli et al., 2001).

The bottlenose dolphin is the second most abundant species in Galician waters. In the north-east Atlantic, bottlenose dolphins are regularly seen off the coasts of Portugal, Spain, France and Ireland (Evans et al., 1993). In the UK, they have a patchy distribution with resident populations in Cardigan Bay in Wales and the Moray Firth in Scotland (Evans, 1980; Hammond \& Thompson, 1991; Wilson et al., 1999). Resident groups have also been recorded in the English Channel off western Brittany (Guinet et al., 1993; Liret et al., 1994) and in the Sado estuary, Portugal (Harzen \& Brunnick, 1996).
In Galicia, Fernández-Cordeiro et al. (1996) noted the presence of a resident population of bottlenose dolphins in the ría de Vigo. The present study also found the species to be concentrated in inshore waters in the southern part of the study area, which includes the ría de Vigo, although it was also seen in deeper waters in the north of Galicia. The latter animals may belong to the 'Vigo' population or could represent a separate offshore population.

Aguilar's (1997) surveys did not extend into the rías and reported sightings of only four groups of bottlenose dolphins. Our data are consistent with a local population numbering between 600 and 1000 animals. Santos (1998) found the main prey of bottlenose dolphins in Galician waters to be blue whiting and hake (Merluccius merluccius). Hake is another important target species of Galician fisheries and large concentrations of recruits are typically present in shelf waters (100-250 m) over winter (October to April) (Fernández et al., 1978). Thus dietary evidence suggests that bottlenose dolphins might be expected to occur in fishery areas, but also that they must routinely travel offshore. Our data suggested that bottlenose dolphins were preferentially associated with use of seine nets and artisanal gears, rather than other types of fishing. This could indicate attraction to particular types of fishing boat or association with particular types of prey. Although the most frequent prey of bottlenose dolphins were blue whiting and hake, which are generally fished by trawlers, a wide range of other fish, cephalopod and crustacean species was recorded in the stomach contents (Santos, 1998).

Porpoises were seen on only three occasions during the present study. As noted by Evans \& Chappell (1994), porpoises are difficult to survey at sea due to their small size and relative inconspicuousness when at the surface. However, Aguilar (1997) recorded sightings of 23 harbour porpoises and commented that it is common off Galicia. Furthermore, 34 porpoises (including nine by-caught animals) were stranded in Galicia during 1998-1999 (López et al., 2002).

Although experienced observers were used, the opportunistic use of fishing vessels as observation platforms limited the type of data collected in the present study. The present study has provided information on patterns of distribution, the abundance estimates derived are clearly at best provisional and there remains a need for dedicated surveys to estimate cetacean abundance in Galician waters. Design of dedicated sighting surveys must consider factors such as choice of survey platform, effects of sea state and visibility conditions on detectability of cetaceans, responses of animals to the survey platform and the proportion of animals that are visible to the observer as a function of distance (Eberhardt, 1978; Hammond, 1984, 1986a,b; Holt \& Cologne, 1987; Edwards \& Kleiber, 1989; Hiby \& Hammond, 1989; Marsh \& Sinclair, 1989; Buckland et al., 1991, 1993; Buckland \& Turnock, 1992; Garner et al., 1999).

Galicia is an important area for cetaceans, not only within Spain but also at the European level and has one of the highest recorded rates of stranding in Europe (e.g. López et al., 2002). Baseline data on cetacean populations are needed against which to evaluate the effects of fishery by-catch and events such as the recent oil spill from the 'Prestige' on the populations. 
The authors gratefully acknowledge the contribution of the observers, fishermen, CEMMA volunteers and colleagues at ECOBIOMAR to data collection. We thank Alex Aguilar for permission to cite his report. The study was funded by the European Commission's Directorate General for Fisheries ('Impact of fisheries on small cetaceans in coastal waters of Northwest Spain and Scotland', Study 97/089). We also thank three anonymous referees for useful comments on an earlier version of the manuscript.

\section{REFERENCES}

Aguilar, A., 1997. Inventario de los cetáceos de las aguas atlánticas peninsulares: aplicación de la directiva 92/43/CEE. Memoria Final. Departamento de Biología Animal (Vert.), Facultad de Biología, Universitat de Barcelona, Spain.

Aguilar, A., Grau, E., Sanpera, C., Jover, L. \& Donovan, G., 1983. Report of the 'Ballena 1' whale marking and sighting cruise in the waters off western Spain. Report of the International Whaling Commission, 33, 649-655.

Aguilar, A. \& Lens, S., 1981. Preliminary report on Spanish whaling activities. Report of the International Whaling Commission, 31, 639-643.

Aguilar, A., Sanpera, C. \& Grau, E., 1985. Further estimate of catch per unit effort as an index of abundance for the fin and sperm whale fishery off Northwestern Spain. Report of the International Whaling Commission, 35, 521-527.

Bloor, P., Reid, J., Webb, A., Begg, G. \& Tasker, M., 1996. The distribution of seabirds and cetaceans between the Shetland and Faroe Islands. Foint Nature Conservation Committee Report, no. 26, $140 \mathrm{pp}$.

Bree, P.J.H. van, 1977. On former and recent strandings of cetaceans on the coast of the Netherlands. Zeitschrift für Säugetierkunde, 42, 101-107.

Buckland, S.T., Anderson, D.R., Burnham, K.P. \& Laake, J.L., 1993. Distance sampling: estimating abundance of biological populations. London: Chapman \& Hall.

Buckland, S.T., Cattanach, K.L. \& Anganuzzi, A.A., 1991. Estimating trends in abundance of dolphins associated with tuna in the eastern tropical Pacific ocean, using sightings collected on commercial tuna vessels. Fishery Bulletin, 90, 1-12.

Buckland, S.T. \& Turnock, B.J., 1992. A robust line transect method. Biometrics, 48, 901-909.

Cabrera, A., 1914. Fauna Ibérica, Mamíferos. Madrid: Museo Nacional de Ciencias Naturales, CSIC.

Casinos, A. \& Vericad, J.-R., 1976. The cetaceans of the Spanish coasts: a survey. Mammalia, 40, 267-289.

Cendrero, O., 1993. Nota sobre los hallázgos de cetáceos en el norte de España. Boletín del Instituto Español de Oceanografía, 9, 251-255.

Collet, A., 1981. Biologique de dauphin commun Delphinus delphis L. en Atlantique Nord-est. PhD thesis, University of Poitiers, Poitiers, France.

De Smet, W.M.A., 1974. Inventaris van de walvisachtigen (Cetacea) van de Vlaamse kust en de Schelde. Bulletin de l'Institut Royal des Sciences Naturelles de Belgique, Biologie, 50, $1-156$.

Dos Santos, M.E., Lacerda, M. \& Sequeira, M.L., 1988. Preliminary aerial surveys in Portuguese coastal waters. In Proceedings of the Second Annual Conference of the European Cetacean Society, Troia, Portugal, 5-7 February 1988. European Research on Cetaceans-2 (ed. P.G.H. Evans), pp. 13-16. Cambridge: European Cetacean Society.

Duguy, R., 1977. Notes on small cetaceans off the coasts of France. Report of the International Whaling Commission, 27, 500-501.

Eberhardt, L.L., 1978. Transect methods for population studies. Fournal of Wildlife Management, 42, 1-31.
Edwards, E.F. \& Klieber, P.M., 1989. Effects of non-randomness on line transect estimates of dolphin school abundance. Fishery Bulletin, 87, 859-876.

Evans, P.G.H., 1980. Cetaceans in British waters. Mammal Review, 10, $1-52$.

Evans, P.G.H. \& Chappell, O., 1994. A comparison of visual and acoustic techniques for surveying harbour porpoises. In Proceedings of the Eighth Annual Conference of the European Cetacean Society, Montpellier, France, 2-5 March 1994. European Research on Cetaceans -8 (ed. P.G.H. Evans), pp. 172-175. Cambridge: European Cetacean Society.

Evans, P.G.H., Lewis, E.J. \& Vodden, P., 1993. Cetaceans in British and Irish waters: the work of Sea Watch Foundation. In Proceedings of the Seventh Annual Conference of the European Cetacean Society, Inverness, Scotland, 18-21 February 1993. European Research on Cetaceans-7 (ed. P.G.H. Evans), pp. 156-160. Cambridge: European Cetacean Society.

Fernández, A., Pereiro, F.X., Iglesias, S., Porteiro, C. \& Pallares, P., 1978. La pesquería demersal gallega. Estrategias de pesca para su regulación racional en base a merluza. Boletín Intituto Español de Oceanografía, 249, 67-109.

Fernández-Cordeiro, A., Torrado-Fernández, F., Pérez-Pintos, R., García-Blanco, M. \& Rodríguez-Folgar, A., 1996. The bottlenose dolphin, Tursiops truncatus, along the Galician coast, with special reference to the ría de Vigo herd. In Proceedings of the Tenth Annual Conference of the European Cetacean Society, Lisbon, Portugal, 11-13 March 1996. European Research on Cetaceans-10 (ed. P.G.H. Evans), pp. 213-216. Cambridge: European Cetacean Society.

Fernández de la Cigoña, E., 1983. Varamientos de ballenas y delfines en Galicia. Revista del Mar, 2, 18-20.

Fernández de la Cigoña, E., 1990. Os cabaleiros do mar: baleas e golfiños das nosas augas. Guía dos cetáceos de Galicia e Iberia. In Natureza Galega. Vol. III. Vigo: Asociación Galega para a Cultura e a Ecoloxía (AGCE).

Fraga, F., 1981. Upwelling off the Galicean coast, Northwest Spain. In Coastal upwelling (ed. F.A. Richards), pp. 176-182. Washington: American Geophysical Union.

Garner, G.W., Amstrup, S.C., Laake, J.L., Manly, B.F.J., McDonald L.L. \& Robertson, D.G., ed., 1999. Marine mammal survey and assessment methods. Rotterdam: A.A. Balkema.

Gaskin, D.E., 1992. Status of the common dolphin, Delphinus delphis, in Canada. Canadian Field Naturalist, 106, 55-63.

Goujon, M., Antoine, L., Collet, L. \& Fifas, S., 1993. Approche de l'impact écologique de la pêcherie thonière au filet maillant derivant en Atlantique nord-est. Rapport interne de la Direction des Resources Vivantes de l'IFREMER, 47 pp.

Grau, E., Aguilar, A. \& Filella, I.S., 1980. Cetaceans stranded, captured or sighted in the Spanish coasts during 1976-1979. Bulletin del Instituto Catalán de Historia Natural, 45, 167-179.

Guerra, A., 1992. Mollusca, Cephalopoda. In Fauna Ibérica, vol. 1 (ed. M.A. Ramos Sánchez et al.). Madrid: Museo Nacional de Ciencias Naturales, CSIC.

Guinet, C., Allali, P., Carcaillet, C., Creton, P., Liret, C. \& Ridoux, V., 1993. Bottle-nose dolphins (Tursiops truncatus) in western Brittany. In Proceedings of the Seventh Annual Conference of the European Cetacean Society, Inverness, Scotland, 18-21 February 1993. European Research on Cetaceans -7 (ed. P.G.H. Evans), pp. 72. Cambridge: European Cetacean Society.

Hammond, P.S., 1984. On the application of line transect sampling to the estimation of the number of Bowhead whales passing the Point Barrow Ice-Camps. Report of the International Whaling Commission, 34, 465-467.

Hammond, P.S., 1986a. Line transect sampling of dolphin populations In Research on dolphins (ed. M.M. Bryden and R.J. Harrison), pp. 251-279. Oxford: Oxford University Press. 
Hammond, P.S., 1986b. On the post-stratification of sightings data from the 1978/79-1982/83 IWC/IDCR southern hemisphere minke whale assessment cruises and survey design for future cruises. Report of the International Whaling Commission, 36, 225-237.

Hammond, P.S., Benke, H., Berggren, P., Collet, A., HeideJorgensen, M.P., Heimlich-Boran, S., Leopold, M. \& Oien, N., 1995. The distribution and abundance of harbour porpoises and other small cetaceans in the North Sea and adjacent waters. International Council for the Exploration of the Sea (CM Papers and Reports), GM 1995/N:10, 240 pp.

Hammond, P.S. \& Thompson, P.M., 1991. Minimum estimate of the number of bottlenose dolphins Tursiops truncatus in the Moray Firth, NE Scotland. Biological Conservation, 56, 79-97.

Harzen, S. \& Brunnick, B.J., 1996. The social structure of the bottlenose dolphin Tursiops truncatus, in the Sado Estuary, Portugal. In Proceedings of the Tenth Annual Conference of the European Cetacean Society, Lisbon, Portugal, 11-13 March 1996. European Research on Cetaceans - 10 (ed. P.G.H. Evans), pp. 212. Cambridge: European Cetacean Society.

Hiby A.R. \& Hammond, P.S., 1989. Survey techniques for estimating the abundance of cetaceans. In The comprehensive assessment of whale stocks: the early years (ed. G.P. Donovan), pp. 47-80. Cambridge: International Whaling Commission.

Holt, R.S. \& Cologne, J., 1987. Factors affecting line transect estimates of dolphin school density. Fournal of Wildlife Management, 51, 837-843.

Lens, S., Quiroga H. \& Gil de Sola, L., 1989. Report of the cruise undertaken by Spain as part of the North Atlantic sightings survey, 1987. Report of the International Whaling Commission, 39, 423-425.

Liret, C, Allali, P., Creton, P., Guinet, C. \& Ridoux, V., 1994. Foraging activity pattern of bottlenose dolphins around Ile de Sein, France and its relationships with environmental parameters. In Proceedings of the Eighth Annual Conference of the European Cetacean Society, Montpellier, France, 2-5 March 1994. European Research on Cetaceans -8 (ed. P.G.H. Evans), pp. 188-189. Cambridge: European Cetacean Society.

López, A., Pierce, G.J., Santos, M.B., Gracia, J. \& Guerra, A., 2003. Fishery by-catches of marine mammals in Galician waters: results from on-board observations and an interview survey of fishermen. Biological Conservation, 111, 25-40.

López, A., Santos, M.B., Pierce, G.J., González, A.F., Valeiras X. \& Guerra, A., 2002. Trends in strandings of cetaceans on the Galician coast, north-west Spain, during the 1990s. Fournal of the Marine Biological Association of the United Kingdom, 82, 513-521.

Marsh, H. \& Sinclair, D.F., 1989. Correcting for visibility bias in strip transect aerial surveys of aquatic fauna. Fournal of Wildlife Management, 53, 1017-1024.

Mizroch, S. \& Sanpera, C., 1984. A preliminary estimate of abundance of fin whales in the Atlantic waters near Spain. Report of the International Whaling Commission, 34, 395-397.

Natoli, A., Cañadas, A., Vaquero, C., Politi, E., Fernánd́ez Piqueras, J. \& Hoelzel, A.R., 2001. Phylogeography of Mediterranean and North Atlantic common dolphin populations. European Research on Cetaceans, 15.
Penas-Patiño, X.M. \& Piñeiro-Seage, A., 1989. Cetáceos, focas e tartarugas das costas ibéricas. Santiago de Compostela: Consellería de Pesca, (Xunta de Galicia).

Raga, J.A., Raduán, M.A. \& Blanco, C., 1985. Contribución al estudio de la distribución de cétaceos en el Mediterráneo y Atlántico Ibérico. Miscelánea Zoológica, 9, 361-366.

Ross, G.J.B., 1984. The smaller cetaceans of the south east coast of southern Africa. Annals of the Cape Provincial Museums (Natural History), 15, 173-410.

Sanpera, C., Aguilar, A., Grau, E., Jover L. \& Mizroch, S., 1984. Report of the 'Ballena 2' whale marking and sighting cruise in the Atlantic waters off Spain. Report of the International Whaling Commission, 34, 663-666.

Sanpera, C., Grau, E., Jover, L., Recasens, E., Aguilar, A., Olmos, M., Collet A. \& Donovan G.P., 1985. Report of the 'Ballena 3' fin whale marking and sightings cruises off Spain, 1983. Report of the International Whaling Commission, 35, 495-497.

Sanpera, C. \& Jover, L., 1985. Population estimates in fin whales inhabiting Atlantic waters near Spain. Report of the International Whaling Commission, 39, 427-429.

Sanpera, C. \& Jover, L., 1986. Results of the 'Ballena 4' fin whale sightings cruise. Report of the International Whaling Commission, 36, 253-255.

Sanpera, C. \& Jover, L., 1989. Density estimate of fin whales in the North Atlantic from NASS-87 Spanish cruise data. Report of the International Whaling Commission, 35, 352-355.

Santos, M.B., 1998. Feeding ecology of harbour porpoises, common and bottlenose dolphins and sperm whales in the Northeast Atlantic. PhD thesis, University of Aberdeen, Aberdeen, UK.

Sequeira, M.L. \& Inácio, A., 1992. Accidental catches of cetaceans in Portugal. In Proceedings of the Sixth Annual Conference of the European Cetacean Society, San Remo, Italy, 20-22 February 1992. European Research on Cetaceans - 6 (ed. P.G.H. Evans), pp. 25-28. Cambridge: European Cetacean Society.

Sequeira, M.L. \& Teixeira, A.M., 1988. Marine mammal surveys in Portugal. In Proceedings of the Second Annual Conference of the European Cetacean Society, Troia, Portugal, 5-7 February 1988. European Research on Cetaceans-2 (ed. P.G.H. Evans), pp. 9-12. Cambridge: European Cetacean Society.

Solórzano, M.R., Rodríguez, J.L., Iglesias, J., Pereiro, F.X. \& Alvarez, F., 1988. Inventario dos peixes do litoral galego. (Pisces: Cyclostomata, Condrichthyes, Osteichthyes). Cadernos da Area de Ciencias Biolóxicas. Seminarios de Estudios Galegos.

Tomilin, A.G., 1957. Cetacea. In Mammals of the U.S.S.R. and adjacent countries, vol. IX (ed. V.G. Geptner). Moscow: Izdat. Akad. Nauk SSSR. [English Translation, 1967, Jerusalem: Israel Program for Scientific Translations.]

Vázquez, R., Barreiro, A., Pérez, M.T. \& López, A., 1996. Varamento masivo de Delphinus delphis en Galicia no 1995. Eubalaena, 9, 22-27.

Wilson, B., Hammond, P.S. \& Thompson, P.M., 1999. Estimating size and assessing trends in a coastal bottlenose dolphin population. Ecological Applications, 9, 288-300.

Submitted 2 September 2002. Accepted 24 November 2003. 